\title{
PEMBERDAYAAN KELOMPOK WANITA TANI MELALUI PENINGKATAN KETERAMPILAN PETANI PETERNAK MELALUI PELATIHAN BUDIDAYA TERNAK KAMBING PERAH
}

\section{EMPOWERMENT OF FARMER WOMEN GROUP THROUGH ENHANCEMENT OF MANAGEMENT SKILLS OF FARMERS THROUGH TRAINING MANAGEMENT OF DAIRY GOATSLIVESTOCK}

\author{
D Sudrajat'a, D Kardaya1, E Dihansih'1 ${ }^{1}$, dan D Wahyuni' \\ ${ }^{1}$ Program Studi Peternakan, Fakultas Pertanian, Universitas Djuanda Bogor, Jl. Tol Ciawi No.1 \\ Kotak Pos 35 Bogor 16720 \\ a Korespondensi: Deden Sudrajat, Email: deden.sudrajat@unida.ac.id \\ (Diterima: 28-11-2017; Ditelaah: 29-11-2017; Disetujui: 17-02-2018)
}

\begin{abstract}
The low productivity of dairy goats in livestock farming is due to poor farming management and lack of technology in management, such as feed technology, reproduction, and technology of livestock products. The Sukamanah village has potential for the development of dairy goats as it is supported by land and weather areas suitable for dairy cultivation and labor availability. But the breeder farmer in this village still do not understand how good management in farming. Training in the form of counseling and direct practice on dairy goat farming management and improvement of dairy cages has been done in Sukamanah village. Farmer farmers enthusiastically follow the extension activities. Extension materials are largely understandable because they are used to nurturing dairy goats and have a desire to develop and improve skills.

Keywords: Etawa breed goat, Sukamanah village.
\end{abstract}

\begin{abstract}
ABSTRAK
Rendahnya produktivitas kambing perah di peternakan rakyat disebabkan karena tata kelola peternakan yang masih minim, dan belum masuknya teknologi dalam manajemen seperti teknologi pakan, reproduksi, dan teknologi hasil ternak. Desa Sukamanah memiliki potensi untuk pengembangan kambing perah karena didukung oleh luas lahan dan cuaca yang cocok untuk budidaya ternak perah dan ketersediaan tenaga kerja. Namun peternak di desa ini masih belum memahami bagaimana manajemen yang baik. Pelatihan dalam bentuk penyuluhan dan praktik langsung mengenai manajemen budidaya kambing perah dan perbaikan kandang kambing perah telah dilakukan di desa Sukamanah. Petani peternak antusias mengikuti kegiatan penyuluhan. Materi penyuluhan sebagian besar dapat dipahami karena mereka sudah terbiasa memelihara kambing perah dan memiliki keinginan untuk mengembangkan dan meningkatkan ketrampilan.
\end{abstract}

Kata kunci: desa Sukamanah, kambing peranakan Etawa.

Sudrajat, D., Kardaya, D., Dihansih, E., \& Wahyuni, D. (2018). Pemberdayaan Kelompok Wanita Tani Melalui Peningkatan Keterampilan Petani Peternak Melalui Pelatihan Budidaya Ternak Kambing Perah. Qardhul Hasan: Media Pengabdian kepada Masyarakat 4(1): 1-5. 


\section{PENDAHULUAN}

Lahan pertanian yang semakin sempit merupakan permasalahan umum yang sedang terjadi di daerah pertanian di pinggiran perkotaan. Petani menghadapi berkurangnya areal lahan yang digunakan untuk bercocok tanam dan mengembangkan produksi pertaniannya. Lahan-lahan pertanian berkurang menjadi perumahan, pabrik bahkan menjadi tempat pariwisata. Akibatnya sumber daya tenaga kerja petani menjadi kurang dimanfaatkan secara optimal. Sebagian besar para petani hanya menjadi petani penggarap menjadi kehilangan pencaharian. Selain bertani, usaha lain yang dilakukan adalah beternak. Sebagian petani, umumnya memiliki ternak kambing, domba, atau sapi perah sebagai usaha sampingan. Peternakan merupakan salah satu usaha yang dapat meningkatkan kesejahteraan petani.

Desa Sukamanah Kecamatan Megamendung merupakan desa daerah pinggiran kota Bogor. Desa tersebut berlokasi berdekatan dengan daerah wisata sehingga lahan pertanian dan peternakan menjadi terbatas. Petani di daerah tersebut belum memaksimalkan potensi yang di miliki oleh mereka. Sebagian besar petani telah memiliki ternak, seperti domba, sapi perah dan kambing perah. Kelompok tani yang terdapat di desa Sukamanah adalah Kelompok Wanita Tani (KWT) Lestari. Kelompok tani ini mempunyai peluang untuk memaksimal anggotanya untuk meningkatkan ketrampilan dalam bidang peternakan. Hal ini karena mereka masih memiliki banyak waktu dan kesempatan untuk melaksanakan kegiatan peternakan di samping sebagai petani.

Potensi ternak lokal sebagai penghasil susu, bisa diperoleh dari ternak sapi bisa juga diperoleh dari ternak kambing perah. Salah satu kambing perah yang berpotensi digunakan adalah kambing peranakan etawah. Kambing peranakan etawah merupakan plasma nutfah Indonesia yang bersifat dwiguna. Kambing Peranakan
Etawah dapat dipelihara sebagai pedaging maupun sebagai kambing perah. Kambing peranakan etawah bisa menghasilkan produksi susu sekitar 0,45 sampai 2,1 liter/hari/laktasi (Andriani et al 2003). Walaupun produksi susu kambing lebih rendah daripada sapi perah, harga susu kambing lebih mahal, bahkan sampai Rp 45.000/liter.

Salah satu faktor yang menyebabkan rendahnya produksi susu adalah dikarenakan sistem usaha peternakan yang belum dikelola dengan baik. Salah satunya ada di daerah Desa Sukamanah, Kecamatan Megamendung memiliki kondisi tanah yang subur untuk penanaman hijauan dan didukung oleh suhu udara yang cocok untuk pengembangan budidaya ternak perah. Beberapa petani peternak telah memilik terak domba maupun kambing perah. Berdasarkan pengamatan di lapangan, kelompok peternak kambing perah dan sapi perah di daerah ini sudah ada namun dalam upaya pemeliharaan manajemen yang dilakukannya masih sangat sederhana. Aspek teknologi belum masuk dalam manajemen di daerah ini baik itu teknologi pakan, reproduksi dan sebagainya. sehingga pendapatan yang diterima oleh peternak masih sangat minim. Seperti sanitasi kandang yang belum dilakukan sehingga tak jarang kambing perah yang dipelihara terkena penyakit kulit (scabies atau kudis) yang disebabkan oleh tungau parasit Sarcoptes scabiei, aspek pakan yang masih belum mencukupi pemenuhan akan protein dan energi. Selain itu peternak masih belum mengetahui informasi mengenai bagaimana cara pengelolaan produk pasca panen yang bisa meningkatkan nilai tambah dari susu. Sehingga peternak bisa menjual bukan hanya susu segar melainkan produk olahan dari susu seperti yoghurt dan permen susu. Berdasarkan hal tersebut, maka kegiatan pengabdian pada masyarakat di desa ini dianggap perlu dilakukan, agar dapat membantu pengetahuan, keterampilan dan pendapatan para peternak di daerah tersebut dapat lebih meningkat. 


\section{MATERI DAN METODE}

\section{Metode Pendekatan}

Agar menjawab setiap permasalahan yang dihadapi mitra, solusi yang ditawarkan adalah dengan transfer pengetahuan melalui kegiatan diskusi, penyuluhan, pelatihan dan praktek. Penyuluhan dilakukan dengan pemaparan dan diskusi. Materi yang disampaikan adalah teknik budidaya ternak perah dan praktik pembuatan model kandang kambing perah dan metode pemerahan. Pada akhir pelatihan diadakan post test untuk mengetahui sampai sejauh mana efektifitas pelatihan yang dilaksanakan terhadap peningkatan pengetahuan dan ketrampilan petani peternak.

\section{Langkah Pemecahan Masalah}

Kegiatan penyuluhan dan praktek yang dapat dilakukan yaitu:

1. Penyuluhan mengenai manajemen perkandangan, pakan dan pemeliharaan secara menyeluruh.

2. Penyuluhan mengenai betapa pentingnya kesehatan bagi ternak untuk penanganan beberapa penyakit yang sering terjadi.

3. Praktik membuat model kandang kambing perah yang sesuai dengan aturan.

4. Praktik melakukan pemerahan kambing perah secara manual

Sasaran peternak yang dituju adalah kelompok petani peternak yang terdiri dari 15 orang anggota. Materi yang diberikan selama 2x 60 menit, yang dimulai pukul 13.00- 17.00 diantaranya diselingi dengan istrahat selama 30 menit. Praktik yang dilakukan terdiri dari praktik mandiri dan pendampingan. Praktik yang dilakukan diantaranya melakukan perbaikan kendang dan praktik pemerahan, Praktik dilakukan masing-masing selama $3 \times 60$ menit.

\section{HASIL DAN PEMBAHASAN}

Tim pengabdian membuat dan menganalisis instrument kuisioner pretest yang akan dilaksanakan kepada peserta program. Di dalam instrument kuisioner kami memasukan biodata peserta dan pengetahuan dasar tentang manajemen ternak perah serta pengolahan produk hasil ternak khususnya susu. Hasil kuisioner menunjukkan, peserta belum mengetahui dengan benar mengenai manajemen produksi ternak perah. Selama ini peternak memelihara kambing perah hanya sebagai ternak pedaging, lalu induk kambing untuk menghasilkan anak. Budidaya ternak kambing di Indonesia maupun di negara tropis lainnya umumunya, masih diutamakan untuk menghasilkan daging sedangkan di negara empat musim, khususnya di beberapa negara di Eropa, memelihara ternak kambing untuk produksi susu. Kambing Saanen, Toggenberg, Anglo Nubian, British Alpin merupakan rumpun kambing dari daerah temperate yang dibentuk khusus untuk tujuan produksi susu (SINN, 1983). Namun dengan program pemeliharaan yang baik seperti manajemen pemeliharaan, pemberikan pakan dan sistem reproduksi yang baik dapat menghasilkan produksi susu yang meningkat (Sutama 2008).

Petani peternak yang mengikuti kegiatan ini berjumlah sekitar 15 orang dengan rentang umur 23 sampai 46 tahun, namun sekitar $75 \%$ berumur 40 tahun lebih. Sistem pemeliharaan kambing dalam kandang, tidak pernah dikeluarkan. Pemberian pakan tidak memperhatikan jumlah kebutuhan dan tidak memperhatikan kualitas pakan. Selang beranak sebagian besar lebih dari 10 bulan. Selang beranak pada pemeliharaan kambing induk yang ideal adalah 8 sampai 10 bulan, anak kambing dibiarkan bersama dengan induk sampai disapih selama 4 bulan. Induk kambing yang sedang menyusui tidak pernah diambil susunya 
selain untuk kebutuhan anaknya. Hal ini dikarenakan produksi air susu kambing jumlahnya masih rendah dan juga peternak belum mengetahui cara pemerahan susu kambing perah. Kandang ternak kambing sebagian besar sudah dalam sistem panggung, Hal ini menunjukkan bahwa para petani peternak telah memahami secara umum tentang pembuatan kandang. Namun demikian pemisahan kandang untuk setiap fase produksi belum diterapkan. Demikian pula kondisi kandang ternak disana ada yang sudah rusak dan kotoran yang jarang dibersihkan terutama pada bagian lantai sangat membahayakan ternak maupun kesehatan peternak. Oleh karena itu upaya perbaikan kandang perlu dilakukan meningkatkan produksi dan kesehatan ternak.

Kegiatan pelatihan dimulai dengan pemberian motivasi kepada petani peternak. Manfaat peningkatkan pengetahuan dan ketrampilan beternak kambing perah. Para peternak antusias mengikuti kegiatan ini. Tema materi yang diberikan pada penyuluhan ini adalah: Teknik budidaya ternak kambing yaitu mengenai cara memelihara ternak kambing yang baik dan benar sesuai anjuran meliputi "Sapta Usaha" atau 7 Usaha yaitu: 1. Pemilihan bibit yang baik 2. Pemberian pakan yang berkualitas dan berkuantitas 3 . Tatalaksana Perkandangan 4. Program Kesehatan Ternak 5. Manajemen Pemeliharaan 6. Penanganan Panen, pasca panen dan pemasaran 7. Manajemen Usaha. Penyuluhan berlangsung cukup lama karena antusias peserta yang sangat baik karena para peserta belum banyak memahami bagaimana beternak kambing perah secara baik guna tujuan produksi susu kambing yang lebih tinggi. Berdasarkan diskusi dan pengamatan kondisi ternak maka dilakukan kegiatan sesuai dengan kebutuhan akan perlunya praktik langsung. Praktik yang dilaksanakan adalah teknik pemerahan kambing perah dengan metode manual dan perbaikan kandang kambing perah.

Penyuluhan perbaikan kandang perlu diberikan karena kondisi perkandangan di sana kurang memenuhi syarat. Materi perbaikan kandang yaitu : konstruksi bangunan kandang, jenis bahan kandang, dan denah kandang yang baik. lokasi kandang, ketersediaan air untuk kandang, lokasi lahan hijauan untuk kebutuhan ternak dan sarana transportasi apabila produk-produk hasil panen dijual (Sujono, 2013). Penyuluhan ini diikuti oleh 8 orang peternak lelaki maupun perempuan. Kegiatan diikuti peserta dengan antusias, mereka banyak bertanya sehubungan dengan dengan lokasi yang terlalu dekat kandang yang tentu kurang baik tentu kurang baik dari segi kesehatan pemilik rumah.

Kandang kambing peternak sebagian besar berada di belakang rumah, peternak beralasan karena: (1) peternak tidak mempunyai lahan yang cukup luas untuk membuat kandang kambing, (2) memudahkan pemeliharaan dan pengawasan kambing karena sebagian besar dekat Rumah dan hanya sebagai kegiatan sampingan, (3) menghindari dari pencurian kambing. Bagi peternak yang tidak bisa memindahkan kandang, penyuluhan ditekankan pada perbaikan kandang. Perbaikan kandang yang dilakukan adalah: perbaikan tempat pakan, perbaikan lantai dan dinding kandang serta perbaikan lantai dasar kandang, tempat jatuhnya feses kambing.

\section{KESIMPULAN DAN IMPLIKASI}

Petani peternak antusias mengikuti kegiatan penyuluhan. Materi penyuluhan sebagian besar dapat dipahami karena mereka sudah terbiasa memelihara kambing perah. Tatalaksana pemeliharaahn kambing perah yang harus diperhatikan peternak adalah pengaturan perkawinan kambing yang belum dimana sebagian besar selang beranak kambing induk 10 sampai 12 bulan. Selain itu tatacara pelaksanaan pemerahan belum mereka pahami dengan baik. Kontruksi dan layout kandang yang tidak benar menyulitkan proses pemeliharaan terutama pemerahan. 
Berdasarkan kesimpulan, kegiatan selanjutnya yang penting dilaksanakan adalah proses pendampingan kepada peternak selama waktu tertentu agar peternak dapat memahami dan trmapil melakukan kegiatan pemeliharaan. Selain itu penyuluhan tentang pemberian pakan dan biosekuriti kendang perlu diberikan.

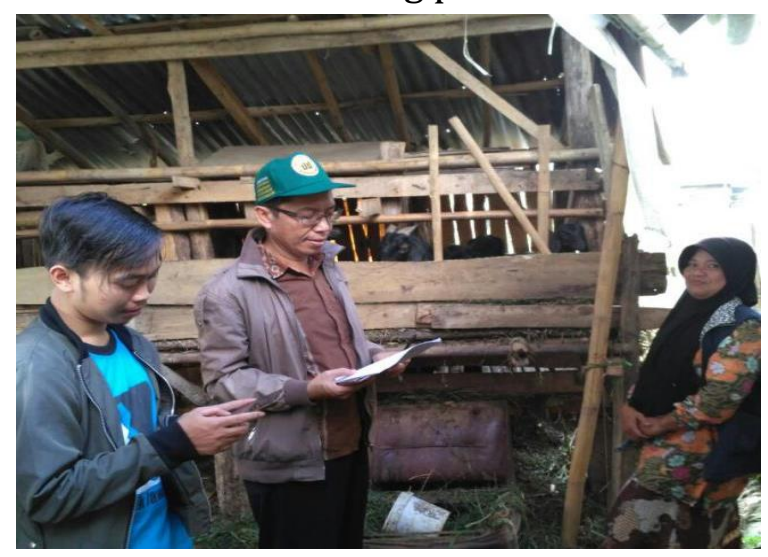

Gambar 1 Kondisi ternak kambing perah, kandang sebelum perbaikan, peternak dan mahasiswa.

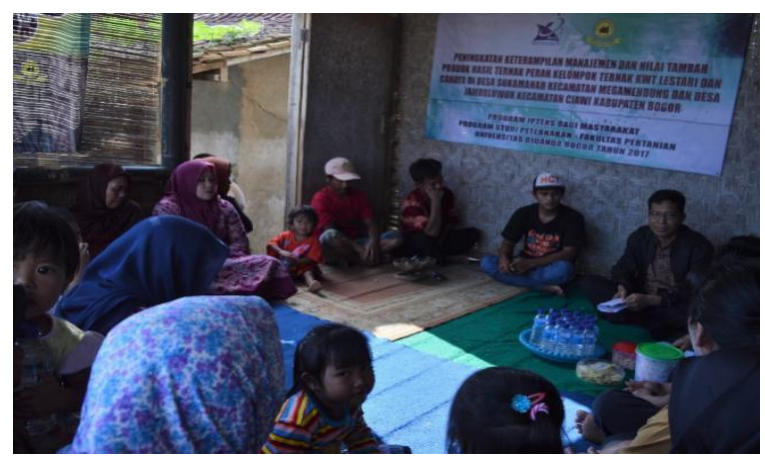

Gambar 2 Kegiatan penyuluhan budidaya ternak perah.

\section{UCAPAN TERIMA KASIH}

Kegiatan ini merupakan sebagian dari kegiatan Program Kemitraan Masyarakat (PKM) Ristekdikti. Oleh karena itu, ucapan terima kasih kami sampaikan kepada Direktorat Riset dan Masyarakat Direktorat Jenderal Penguatan Riset dan Pengembangan Kemristekdikti dengan nomor kontrak 1602/K4/KM/2017 atas pendanaan melalui kegiatan PKM pada tahun 2017.

\section{DAFTAR PUSTAKA}

Adriani, A. Sudono, T. Sutardi, W. Manalu Dan I-K. Sutama. 2003. Optimasi produksi anak dan susu kambing Peranakan Etawah dengan superovulasi dan suplementasi seng. Forum Pascasarjana. Sekolah Pascasarjana, Institut Pertanian Bogor 26(4): 335 - 352.

Sujono, A.Y., 2013. Pendampingan Agribisnis Kambing Peranakan Etawah Dalam Mendukung Kota Batu Sebagai Sentra Produksi Susu. Dedikasi, 10, pp.55-64.

Sutama, I., 2008. Pemanfaatan Sumberdaya Ternak Lokal Sebagai Ternak Perah Mendukung Peningkatan Produksi Susu Nasional. Wartazoa, 18(4), pp.207-217.

SINN, R. 1983. Raising goat for milk and meat. Heifer Project International, Little Rock, Arkansas. 